\title{
UPAYA MENINGKATKAN PRESTASI BELAJAR IPA DENGAN METODE PEMBELAJARAN PENEMUAN (DISCOVERY)
}

\author{
Ngatono \\ Sekolah Dasar Negeri Kranji I \\ Kecamatan Paciran, Kabupaten Lamongan
}

\begin{abstract}
The study aimed to know (1) the improvement of students achievement after applying the Discovery learning method, (2) the influence of the students achievement after applying the Discovery learning method. The study used classroom action research with three cycles. Each cycle consisted of four phases, those are planning, action and observation, reflection, and revision. The subject was the sixth graders of the odd semester at the first state senior high school Kranji, Paciran District, Lamongan Regency. The data collection was from the result of formative test, the observation sheet of teaching and learning activity. The analysis result showed that the students achievement has improved from the first cycle antil the third cycle, the first cycle (58,33\%), the second cycle (75\%), the third cycle (91,33\%). The conclusion of the study was he discovery learning can give the positive influence to the students achievement on the Science lesson in the first state elementary school Kranji, Paciran District, Lamongan Regency.
\end{abstract}

Keywords: science learning, discovery learning

Abstrak: Tujuan penelitian tindakan ini adalah ingin mengetahui (1) peningkatan prestasi belajar siswa setelah diterapkannya pembelajaran penemuan (discovery), (2) pengaruh motivasi belajar siswa setelah diterapkannya metode pembelajaran penemuan (discovery). Penelitian ini menggunakan penelitian tindakan (action research) sebanyak tiga putaran. Setiap putaran terdiri dari empat tahap yaitu: rancangan, kegiatan dan pengamatan, refleksi, dan refisi. Subjek penelitian ini adalah siswa kelas VI Semester Gasal SDN Kranji I Kecamatan Paciran Kabupaten Lamongan. Data yang diperoleh berupa hasil tes formatif, lembar observasi kegiatan belajar mengajar. Dari hasil analisis didapatkan bahwa prestasi belajar siswa mengalami peningkatan dari siklus I sampai siklus III yaitu, siklus I $(58,33 \%)$, siklus II $(75 \%)$, siklus III (91,33\%). Simpulan penelitian ini adalah metode penemuan (discovery) dapat berpengaruh positif terhadap prestasi belajar IPA Siswa SDN Kranji I Kecamatan Paciran Kabupaten Lamongan.

Kata kunci: pembelajaran IPA, metode penemuan (discovery)

PENDAHULUAN

Berhasilnya tujuan pembelajaran ditentukan oleh banyak faktor diantaranya adalah faktor guru dalam melaksanakan proses belajar mengajar, karena guru secara langsung dapat mempengaruhi, membina dan meningkatkan kecerdasan serta keterampilan siswa. Untuk mengatasi permasalahan di atas dan guna mencapai 
tujuan pendidikan secara maksimal, peran guru sangat penting dan diharapkan guru memiliki cara/model mengajar yang baik dan mampu memilih model pembelajaran yang tepat dan sesuai dengan konsepkonsep mata pelajaran yang akan disampaikan.

Untuk itu diperlukan suatu upaya dalam rangka meningkatkan mutu pendidikan dan pengajaran salah satunya adalah dengan memilih strategi atau cara dalam menyampaikan materi pelajaran agar diperoleh peningkatan prestasi belajar siswa khususnya pelajaran IPA. Misalnya dengan membimbing siswa untuk bersama-sama terlibat aktif dalam proses pembelajaran dan mampu membantu siswa berkembang sesuai dengan taraf intelektualnya akan lebih menguatkan pemahaman siswa terhadap konsep-konsep yang diajarkan. Pemahaman ini memerlukan minat dan motivasi. Tanpa adanya minat menandakan bahwa siswa tidak mempunyai motivasi untuk belajar. Untuk itu, guru harus memberikan suntikan dalam bentuk motivasi sehingga dengan bantuan itu anak didik dapat keluar dari kesulitan belajar.

Berdasarkan pengalaman penulis di lapangan, kegagalan dalam belajar ratarata dihadapi oleh sejumlah siswa yang tidak memiliki dorongan belajar. Untuk itu dibutuhkan suatu kegiatan yang dilakukan oleh guru dengan upaya membangkitkan motivasi belajar siswa, misalnya dengan membimbing siswa untuk terlibat langsung dalam kegiatan yang melibatkan siswa serta guru yang berperan sebagai pembimbing untuk menemukan konsep IPA.

Motivasi tidak hanya menjadikan siswa terlibat dalam kegiatan akademik, motivasi juga penting dalam menentukan seberapa jauh siswa akan belajar dari suatu kegiatan pembelajaran atau seberapa jauh menyerap informasi yang disajikan kepada mereka. Siswa yang termotivasi untuk belajar sesuatu akan menggunakan proses kognitif yang lebih tinggi dalam mempelajari materi itu, sehingga siswa itu akan meyerap dan mengendapan materi itu dengan lebih baik. Tugas penting guru adalah merencanakan bagaimana guru mendukung motivasi siswa (Nur, 2001: 3). Untuk itu sebagai seorang guru disamping menguasai materi, juga diharapkan dapat menetapkan dan melaksanakan penyajian materi yang sesuai kemampuan dan kesiapan anak, sehingga menghasilkan penguasaan materi yang optimal bagi siswa.

Berdasarkan uraian tersebut di atas penulis mencoba menerapkan salah satu metode pembelajaran, yaitu metode pembelajaran penemuan (discovery) untuk mengungkapkan apakah dengan model penemuan (discovery) dapat meningkatkan motivasi belajar dan prestasi belajar IPA. Penulis memilih metode pembelajaran ini mengkondisikan siswa untuk terbiasa menemukan, mencari, mendikusikan sesuatu yang berkaitan dengan pengajaran. (Siadari,

2001: 4). Dalam metode pembelajaran penemuan (discovery) siswa lebih aktif dalam memecahkan untuk menemukan sedang guru berperan sebagai pembimbing atau memberikan petunjuk cara memecahkan masalah itu.

Dari latar belakang di atas maka penulis dalam penelitian ini mengambil judul "Upaya Meningkatkan Prestasi Belajar IPA dengan Metode Pembelajaran Penemuan (Discovery) Pada Siswa Kelas VI SDN Kranji I Kecamatan Paciran,Kabupaten Lamongan, Tahun Pelajaran 2016/2017.

Penelitian ini bertujuan untuk:

1. mengetahui peningkatan prestasi belajar siswa setelah diterapkannya pembelajaran penemuan (discovery).

2. mengetahui pengaruh motivasi belajar siswa setelah diterapkan pembelajaran penemuan (discovery) 
Motivasi adalah suatu kondisi yang mendorong seseorang untuk berbuat sesuatu dalam mencapai tujuan tertetntu. Siswa yang termotivasi untuk belajar sesuatu akan menggunakan proses kognitif yang lebih tinggi dalam mempelajari materi itu, sehingga siswa itu akan menyerap dan mengendapkan materi itu dengan lebih baik (Nur, 2001:

3). Sedangkan prestasi belajar adalah hasil yang dicapai oleh siswa dengan melibatkan seluruh potensi yang dimilikinya setelah siswa itu melakukan kegiatan belajar.

Sedangkan metode pembelajaran penemuan (discovery) adalah suatu metode pembelajaran yang memberikan kesempatan dan menuntut siswa terlibat secara aktif di dalam mencapai tujuan pembelajaran dengan memberikan informasi singkat (Siadari, 2001: 7). Pengetahuan yang diperoleh dengan belajar penemuan (discovery) akan bertahan lama, mempunyai efek transfer yang lebih baik dan meningkatkan siswa dan kemampuan berfikir secara bebas. Secara umum belajar penemuan (discovery) ini melatih keterampilan kognitif untuk menemukan dan memecahkan masalah tanpa pertolongan orang lain. Selain itu, belajar penemuan membangkitkan keingintahuan siswa, memberi motivasi untuk bekerja sampai menemukan jawaban (Syafi'udin, 2002: 19).

Dari uraian tersebut di atas dapat disimpulkan bahwa dengan adanya motivasi dalam pembelajaran model penemuan (discovery) tersebut maka hasil-hasil belajar akan menjadi optimal. Makin tepat motivasi yang diberikan, akan makin berhasil pula pelajaran itu. Dengan motivasi yang tinggi maka intensitas usaha belajar siswa akan tingi pula. Jadi motivasi akan senantiasa menentukan intesitas usaha belajar siswa. Hasil ini akan dapat meningkatkan prestasi belajar siswa.

\section{METODE PENELITIAN}

Penelitian ini merupakan penelitian tindakan (action research), karena penelitian dilakukan untuk memecahkan masalah pembelajaran di kelas. Penelitian ini juga termasuk penelitian deskriptif, sebab menggambarkan bagaimana suatu teknik pembelajaran diterapkan dan bagaimana hasil yang diinginkan dapat dicapai. Penelitian ini mengacu pada perbaikan pembelajaran yang berkesinambungan. Kemmis dan Taggart (1988:14) menyatakan bahwa model penelitian tindakan adalah berbentuk spiral. Tahapan penelitian tindakan pada suatu siklus meliputi perencanaan atau pelaksanaan observasi dan refleksi.

Subjek penelitian adalah siswa- siswi kelas VI SDN Kranji I Kecamatan Paciran, Kabupaten Lamongan, pada pokok bahasan faktor-faktor yang mempengaruhi keseimbangan ekosistem.

Instrumen yang digunakan dalam penelitian ini terdiri atas silabus, RPP, LKS, lembar observasi kegiatan belajar mengajar, dan tes formatif.

Penelitian ini menggunakan teknik analisis deskriptif kualitatif, yaitu suatu metode penelitian yang bersifat menggambarkan kenyataan atau fakta sesuai dengan data yang diperoleh dengan tujuan untuk mengetahui prestasi belajar yang dicapai siswa juga untuk memperoleh respon siswa terhadap kegiatan pembelajaran serta aktivitas siswa selama proses pembelajaran.

Untuk menganalisis tingkat keberhasilan atau persentase keberhasilan siswa setelah proses belajar mengajar setiap putarannya dilakukan dengan cara memberikan evaluasi berupa soal tes tertulis pada setiap akhir putaran. Analisis ini dihitung dengan menggunakan statistik sederhana 
HASIL PENELITIAN DAN

PEMBAHASAN

\section{Analisis Data Penelitian Persiklus}

\section{Siklus I}

\section{Tahap Perencanaan}

Pada tahap ini peneliti mempersiapkan perangkat pembelajaran yang terdiri dari rencana pelajaran 1, LKS 1, soal tes formatif 1, dan alat-alat pengajaran yang mendukung.

\section{Tahap Kegiatan dan Pelaksanaan}

Pelaksanaan kegiatan belajar mengajar untuk siklus I dilaksanakan pada tanggal 16 September 2016 di kelas VI dengan jumlah siswa 12 siswa. Dalam hal ini peneliti bertindak sebagai guru. Adapun proses belajar mengajar mengacu pada rencana pelajaran yang telah dipersiapkan. Pengamatan (observasi) dilaksanakan bersamaan dengan pelaksanaan belajar mengajar.

Pada akhir proses belajar mengajar siswa diberi tes formatif I dengan tujuan untuk mengetahui tingkat keberhasilan siswa dalam proses belajar mengajar yang telah dilakukan. Adapun data hasil penelitian pada siklus I adalah sebagai berikut:

Tabel 4.1 Pengelolan Pembelajaran Pada Siklus I

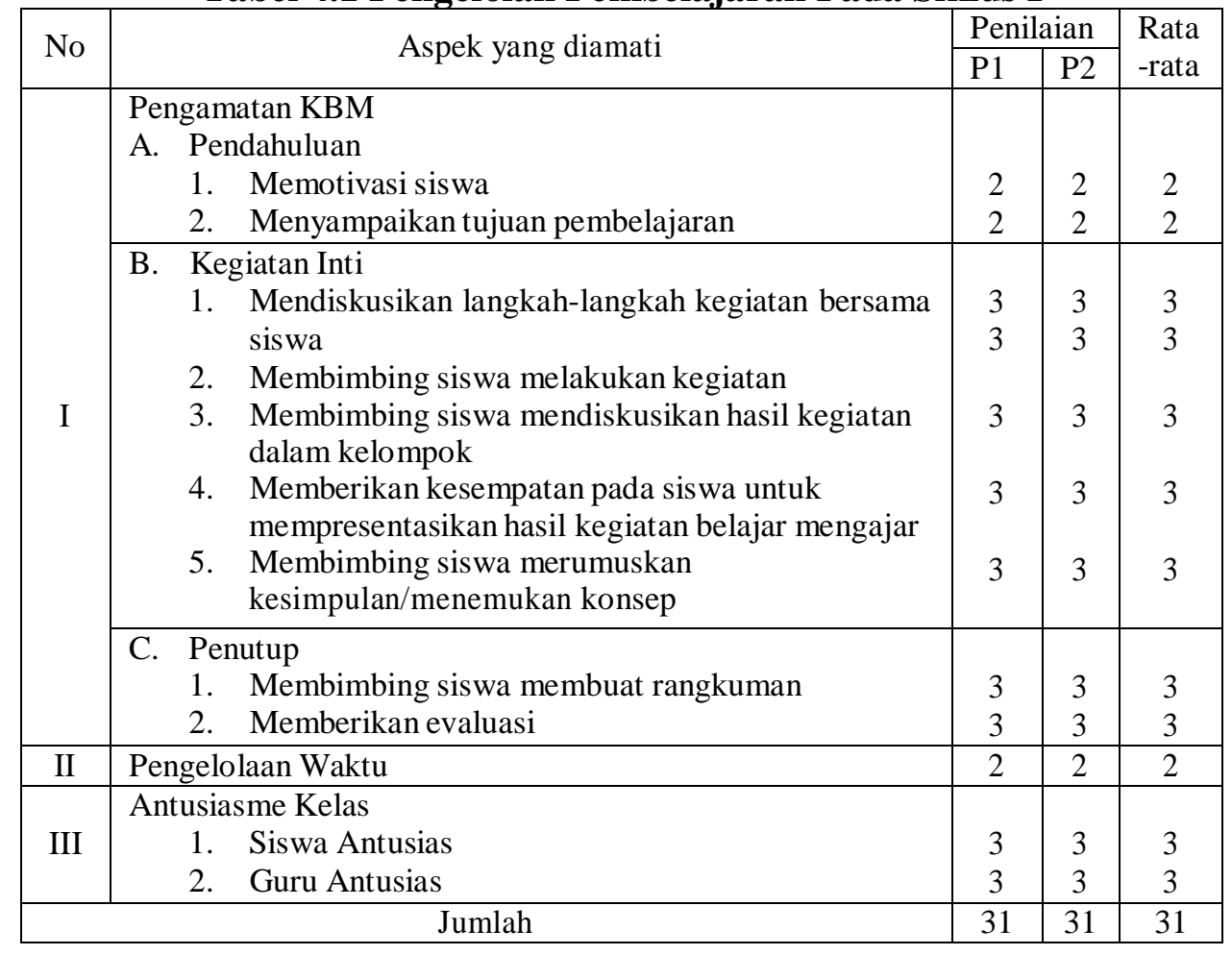

Berdasarkan tabel di atas aspekaspek yang mendapatkan kriteria kurang baik adalah memotivasi siswa, menyampaikan tujuan pembelajaran, pengelolaan waktu. Ketiga aspek yang mendapat penilaian kurang baik di atas, merupakan suatu kelemahan yang terjadi pada siklus I. Dan akan dijadikan bahan kajian untuk refleksi dan revisi yang akan dilakukan pada siklus II.

Hasil observasi berikutnya adalah aktivitas guru dan siswa seperti pada tabel berikut. 
Tabel 4.2. Aktivitas Guru Dan Siswa Pada Siklus I

\begin{tabular}{|c|l|c|}
\hline No & \multicolumn{1}{|c|}{ Aktivitas Guru yang diamati } & Persentase \\
\hline 1 & Menyampaikan tujuan & 6.67 \\
2 & Memotivasi siswa/merumuskan masalah & 10.00 \\
3 & Mengkaitkan dengan pelajaran berikutnya & 8.33 \\
4 & Menyampaikan materi/langkah-langkah/strategi & 5.00 \\
5 & Menjelaskan materi yang sulit & 18.33 \\
6 & Membimbing dan mengamati siswa dalam menemukan konsep & 20.00 \\
7 & Meminta siswa menyajikan dan mendiskusikan hasil kegiatan & 10.00 \\
8 & Memberikan umpan balik & 15.00 \\
9 & Membimbing siswa merangkum pelajaran & 6.67 \\
\hline No & \multicolumn{1}{|c|}{ Aktivitas Siswa yang diamati } & Persentase \\
\hline 1 & Mendengarkan/memperhatikan penjelasan guru & 20 \\
2 & Membaca buku siswa & 12,08 \\
3 & Bekerja dengan sesama anggota kelompok & 18,33 \\
4 & Diskusi antar siswa/antara siswa dengan guru & 14,58 \\
5 & Menyajikan hasil pembelajaran & 5 \\
6 & Mengajukan/menanggapi pertanyaan/ide & 6,67 \\
7 & Menulis yang relevan dengan KBM & 8,33 \\
8 & Merangkum pembelajaran & 7,08 \\
9 & Mengerjakan tes evaluasi & 7,92 \\
\hline
\end{tabular}

Berdasarkan tabel di atas tampak bahwa aktivitas guru yang paling dominan pada siklus I adalah membimbing dan mengamati siswa dalam menemukan konsep yaitu masingmasing dan menjelaskan materi yang sulit 20,00 dan 18,33\%. Aktivitas lain yang persentasenya cukup besar adalah memberi umpan balik yaitu $15,00 \%$. Sedangkan aktivitas siswa yang paling dominan adalah mengerjakan/memperhatikan penjelasan guru yaitu 20,63\%. Aktivitas lain yang persentasenya cukup besar adalah bekerja dengan sesama anggota kelompok, diskusi antar siswa/antara siswa dengan guru, dan membaca buku yaitu masingmasing $18,33 \%, 14,58$ dan $12,08 \%$.

Pada siklus I, secara garis besar kegiatan belajar mengajar dengan metode pembelajaran penemuan (discovery) sudah dilaksanakan dengan baik, walaupun peran guru masih cukup dominan untuk memberikan penjelasan dan arahan karena model tersebut masih dirasakan baru oleh siswa.

Berikutnya adalah rekapitulasi hasil tes formatif siswa seperti terlihat pada tabel berikut.

Tabel 4.3. Rekapitulasi Hasil Tes Siklus I

\begin{tabular}{|c|l|c|}
\hline No & \multicolumn{1}{|c|}{ Uraian } & Hasil Siklus I \\
\hline 1 & Nilai rata-rata tes formatif & 70,00 \\
2 & Jumlah siswa yang tuntas belajar & 7 \\
3 & Persentase ketuntasan belajar & 58.33 \\
\hline
\end{tabular}

Dari tabel di atas dapat dijelaskan bahwa dengan menerapkan metode pembelajaran penemuan (discovery) diperoleh nilai rata-rata prestasi belajar siswa adalah 70,00 dan ketuntasan belajar mencapai 58,33\% atau ada 7 siswa dari 12 siswa sudah tuntas belajar. Hasil tersebut menunjukkan bahwa pada siklus pertama secara klasikal siswa belum tuntas belajar, karena siswa yang memperoleh nilai $\geq 65$ hanya sebesar $58,33 \%$ lebih kecil dari persentase ketuntasan yang dikehendaki yaitu sebesar $85 \%$. Hal ini disebabkan karena siswa masih merasa baru dan belum mengerti apa yang dimaksudkan dan 
digunakan guru dengan menerapkan metode pembelajaran penemuan (discovery).

\section{Siklus II}

\section{Tahap perencanaan}

Pada tahap ini peneliti mempersiapkan perangkat pembelajaran yang terdiri dari rencana pelajaran 2, LKS 2, soal tes formatif II, dan alat-alat pengajaran yang mendukung.

\section{Tahap kegiatan dan pelaksanaan}

Pelaksanaan kegiatan belajar mengajar untuk siklus II dilaksanakan pada tanggal 23 September 2016 di kelas VI dengan jumlah siswa 12 siswa.
Dalam hal ini peneliti bertindak sebagai guru. Adapun proses belajar mengajar mengacu pada rencana pelajaran dengan memperhatikan revisi pada siklus I, sehingga kesalahan atau kekurangan pada siklus I tidak terulang lagi pada siklus II. Pengamatan (observasi) dilaksanakan bersamaan dengan pelaksanaan belajar mengajar.

Pada akhir proses belajar mengajar siswa diberi tes formatif II dengan tujuan untuk mengetahui tingkat keberhasilan siswa selama proses belajar mengajar yang telah dilakukan. Instrument yang digunakan adalah tes formatif II. Adapun data hasil penelitian pada siklus II adalah sebagai berikut.

Tabel 4.4. Pengelolaan Pembelajaran Pada Siklus II

\begin{tabular}{|c|c|c|c|c|}
\hline \multirow{2}{*}{ No } & \multirow{2}{*}{ Aspek yang diamati } & \multicolumn{2}{|c|}{ Penilaian } & \multirow{2}{*}{$\begin{array}{l}\text { Rata } \\
\text {-rata }\end{array}$} \\
\hline & & $\mathrm{P} 1$ & $\mathrm{P} 2$ & \\
\hline \multirow{3}{*}{ I } & $\begin{array}{l}\text { Pengamatan KBM } \\
\text { A. Pendahuluan } \\
\text { 1. Memotivasi siswa } \\
\text { 2. Menyampaikan tujuan pembelajaran }\end{array}$ & $\begin{array}{l}3 \\
3\end{array}$ & $\begin{array}{l}3 \\
3\end{array}$ & $\begin{array}{l}3 \\
3\end{array}$ \\
\hline & $\begin{array}{l}\text { B. Kegiatan Inti } \\
\text { 1. Mendiskusikan langkah-langkah kegiatan } \\
\text { bersama siswa } \\
\text { 2. Membimbing siswa melakukan kegiatan } \\
\text { 3. Membimbing siswa mendiskusikan hasil } \\
\text { kegiatan dalam kelompok } \\
\text { 4. Memberikan kesempatan pada siswa untuk } \\
\text { mempresentasikan hasil kegiatan belajar } \\
\text { mengajar } \\
\text { 5. Membimbing siswa merumuskan } \\
\text { kesimpulan/menemukan konsep }\end{array}$ & $\begin{array}{l}4 \\
4 \\
3\end{array}$ & $\begin{array}{l}4 \\
4 \\
3\end{array}$ & $\begin{array}{l}4 \\
4 \\
3\end{array}$ \\
\hline & $\begin{array}{l}\text { C. Penutup } \\
\text { 1. Membimbing siswa membuat rangkuman } \\
\text { 2. Memberikan evaluasi }\end{array}$ & $\begin{array}{l}3 \\
4\end{array}$ & $\begin{array}{l}4 \\
4\end{array}$ & $\begin{array}{c}3,5 \\
4\end{array}$ \\
\hline II & Pengelolaan Waktu & 3 & 3 & 2 \\
\hline III & $\begin{array}{cl}\text { Antusiasme Kelas } \\
\text { 1. } & \text { Siswa Antusias } \\
\text { 2. } & \text { Guru Antusias }\end{array}$ & $\begin{array}{l}4 \\
4\end{array}$ & $\begin{array}{l}3 \\
4\end{array}$ & $\begin{array}{c}3,5 \\
4\end{array}$ \\
\hline & Jumlah & 42 & 42 & 42 \\
\hline
\end{tabular}

Dari tabel diatas, tampak aspekaspek yang diamati pada kegiatan belajar mengajar (siklus II) yang dilaksanakan oleh guru dengan menerapkan metode pembelajaran penemuan (discovery) mendapatkan penilaian yang cukup baik dari pengamat. Maksudnya dari seluruh penilaian tidak terdapat nilai kurang. Namum demikian penilaian tersebut belum merupakan hasil yang optimal, untuk itu ada beberapa aspek yang perlu mendapatkan perhatian untuk penyempurnaan penerapan pembelajaran selanjutnya. Aspek-aspek tersebut adalah 
memotivasi siswa, membimbing siswa merumuskan kesimpulan/menemukan konsep, dan pengelolaan waktu.

Dengan penyempurnaan aspekaspek di atas dalam penerapan metode pembelajaran penemuan (discovery) diharapkan siswa dapat menyimpulkan apa yang telah mereka pelajari dan mengemukakan pendapatnya sehingga mereka akan lebih memahami tentang apa yang telah mereka lakukan.

Berikut disajikan hasil observasi aktivitas guru dan siswa:

Tabel 4.5 Aktivitas Guru Dan Siswa Pada Siklus II

\begin{tabular}{|c|l|c|}
\hline No & \multicolumn{1}{|c|}{ Aktivitas Guru yang diamati } & Persentase \\
\hline 1 & Menyampaikan tujuan & 6.67 \\
2 & Memotivasi siswa/merumuskan masalah & 6.67 \\
3 & Mengkaitkan dengan pelajaran berikutnya & 6.67 \\
4 & Menyampaikan materi/langkah-langkah/strategi & 11.67 \\
5 & Menjelaskan materi yang sulit & 11.67 \\
6 & Membimbing dan mengamati siswa dalam menentukan konsep & 25.00 \\
7 & Meminta siswa menyajikan dan mendiskusikan hasil kegiatan & 8.33 \\
8 & Memberikan umpan balik & 16.67 \\
9 & Membimbing siswa merangkum pelajaran & 6.67 \\
\hline No & \multicolumn{1}{|c|}{ Aktivitas Siswa yang diamati } & Persentase \\
\hline 1 & Mendengarkan/memperhatikan penjelasan guru & 17.50 \\
2 & Membaca buku siswa & 15,42 \\
3 & Bekerja dengan sesama anggota kelompok & 18,33 \\
4 & Diskusi antar siswa/antara siswa dengan guru & 13.75 \\
5 & Menyajikanhasil pembelajaran & 5.83 \\
6 & Mengajukan/menanggapi pertanyaan/ide & 6,67 \\
7 & Menulis yang relevan dengan KBM & $7, .08$ \\
8 & Merangkum pembelajaran & 6,67 \\
9 & Mengerjakan tes evaluasi/latihan & 8,75 \\
\hline
\end{tabular}

Berdasarkan tabel di atas tampak bahwa aktivitas guru yang paling dominan pada siklus II adalah membimbing dan mengamati siswa dalam menentukan konsep yaitu $25.00 \%$, memberikan umpan balik yaitu $16,67 \%$, kemudian menyampaikan langkahlangkah strategis dan memberi umpan balik yaitu masing-masing 11,67\%.
Sedangkan untuk aktivitas siswa yang paling dominan pada siklus II adalah bekerja dengan sesama anggota kelompok, mendengarkan penjelasan guru, membaca buku, dan diskusi antar siswa/antara siswa dengan guru yaitu $18,33 \%, 17,50 \%, 15,42 \%$ dan $13.75 \%$.

Berikutnya adalah rekapitulasi hasil tes formatif siswa terlihat pada tabel berikut.

Tabel 4.6. Rekapitulasi Hasil Tes Siklus II

\begin{tabular}{|c|l|c|}
\hline No & \multicolumn{1}{|c|}{ Uraian } & Hasil Siklus II \\
\hline 1 & Nilai rata-rata tes formatif & 75 \\
2 & Jumlah siswa yang tuntas belajar & 9 \\
3 & Persentase ketuntasan belajar & 75 \\
\hline
\end{tabular}

Dari tabel di atas diperoleh nilai ratarata prestasi belajar siswa adalah 75 dan ketuntasan belajar mencapai $75 \%$ atau ada 9 siswa dari 12 siswa sudah tuntas belajar. Hasil ini menunjukkan bahwa pada siklus II ini ketuntasan belajar secara klasikal telah megalami peningkatan sedikit lebih baik dari siklus I. Adanya peningkatan hasil belajar siswa ini karena setelah guru menginformasikan bahwa setiap akhir pelajaran akan selalu diadakan tes 
sehingga pada pertemuan berikutnya siswa lebih termotivasi untuk belajar. Selain itu siswa juga sudah mulai mengerti apa yang dimaksudkan dan diinginkan guru dengan menerapkan metode pembelajaran penemuan (discovery).

\section{Siklus III}

\section{Tahap Perencanaan}

Pada tahap ini peneliti mempersiapkan perangkat pembelajaran yang terdiri dari rencana pelajaran 3 , LKS 3, soal tes formatif 3, dan alat-alat pengajaran yang mendukung

\section{Tahap kegiatan dan pengamatan}

Pelaksanaan kegiatan belajar mengajar untuk siklus III dilaksanakan pada tanggal 5 Nopember 2016 di kelas VI dengan jumlah siswa 12 siswa. Dalam hal ini peneliti bertindak sebagai guru. Adapun proses belajar mengajar mengacu pada rencana pelajaran dengan memperhatikan revisi pada siklus II, sehingga kesalahan atau kekurangan pada siklus II tidak terulang lagi pada siklus III. Pengamatan (observasi) dilaksanakan bersamaan dengan pelaksanaan belajar mengajar.

Pada akhir proses belajar mengajar siswa diberi tes formatif III dengan tujuan untuk mengetahui tingkat keberhasilan siswa dalam proses belajar mengajar yang telah dilakukan. Instrumen yang digunakan adalah tes formatif III. Adapun data hasil peneitian pada siklus III adalah sebagai berikut:

Tabel 4.7 Pengelolaan Pembelajaran Pada Siklus III

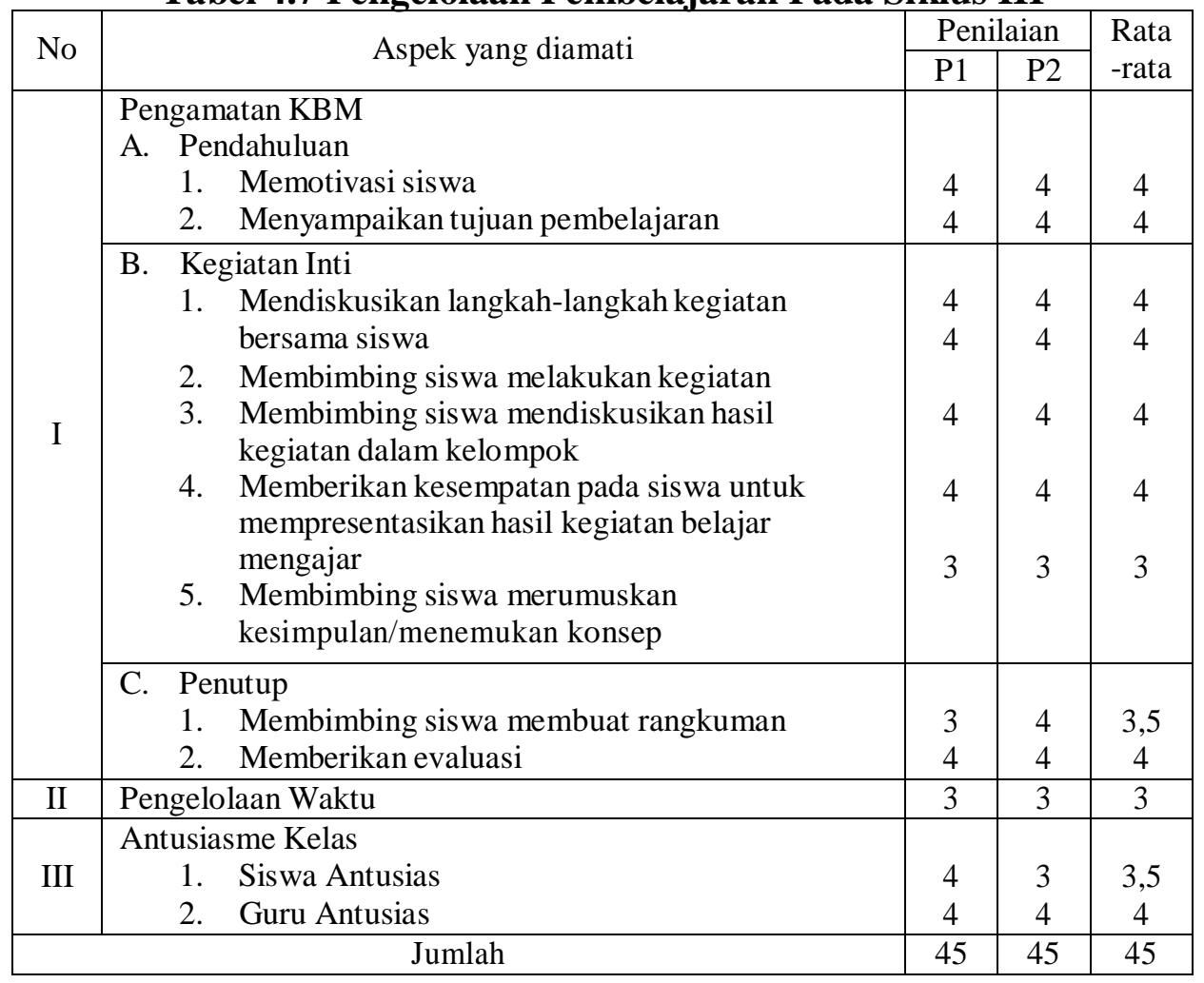

Dari tabel di atas, dapat dilihat aspek-aspek yang diamati pada kegiatan belajar mengajar (siklus III) yang dilaksanakan oleh guru dengan menerapkan metode pembelajaran penemuan (discovery) mendapatkan penilaian cukup baik dari pengamat adalah memotivasi siswa, membimbing siswa merumuskan 
kesimpulan/menemukan konsep, dan pengelolaan waktu.

Penyempurnaan aspek-aspek diatas dalam menerapkan metode pembelajaran penemuan (discovery) diharapkan dapat berhasil semaksimal mungkin.

Berikut disajikan hasil observasi aktivitas guru dan siswa.

Tabel 4.8 Aktivitas Guru Dan Siswa Pada Siklus III

\begin{tabular}{|c|l|c|}
\hline No & \multicolumn{1}{|c|}{ Aktivitas Guru yang diamati } & Persentase \\
\hline 1 & Menyampaikan tujuan & 6.67 \\
2 & Memotivasi siswa/merumuskan masalah & 6.67 \\
3 & Mengkaitkan dengan pelajaran berikutnya & 10.00 \\
4 & Menyampaikan materi/langkah-langkah/strategi & 13.33 \\
5 & Menjelaskan materi yang sulit & 10.00 \\
6 & Membimbing dan mengamati siswa dalam menentukan konsep & 21.67 \\
7 & Meminta siswa menyajikan dan mendiskusikan hasil kegiatan & 10.00 \\
8 & Memberikan umpan balik & 11.67 \\
9 & Membimbing siswa merangkum pelajaran & 10.00 \\
\hline No & \multicolumn{1}{|c|}{ Aktivitas Siswa yang diamati } & Persentase \\
\hline 1 & Mendengarkan/memperhatikan penjelasan guru & 17,92 \\
2 & Membaca buku siswa & 13,75 \\
3 & Bekerja dengan sesama anggota kelompok & 18,75 \\
4 & Diskusi antar siswa/antara siswa dengan guru & 16,25 \\
5 & Menyajikan hasil pembelajaran & 5,83 \\
6 & Mengajukan/menanggapi pertanyaan/ide & 6,67 \\
7 & Menulis yang relevan dengan KBM & 6.25 \\
8 & Merangkum pembelajaran & 7,50 \\
9 & Mengerjakan tes evaluasi/latihan & 7,08 \\
\hline
\end{tabular}

Berdasarkan tabel di atas tampak bahwa aktivitas guru yang paling dominan pada siklus III adalah membimbing dan mengamati siswa dalam menemukan konsep yaitu $21.67 \%$, menyampaikan langkah-langkah strategis yaitu $13,33 \%$ dan memberi umpan balik yaitu $11,67 \%$. Sedangkan untuk aktivitas siswa yang paling dominan pada siklus
III adalah bekerja dengan anggota kelompok yaitu 18,75 mendengarkan dan memperhatikan penjelasan guru yaitu $17,92 \%$ dan diskusi antar siswa/antara siswa dan guru yaitu $16,25 \%$.

Berikutnya adalah rekapitulasi hasil tes formatif siswa seperti terlihat pada tabel berikut

Tabel 4.9. Rekapitulasi Hasil Tes Siklus III

\begin{tabular}{|c|l|c|}
\hline No & \multicolumn{1}{|c|}{ Uraian } & Hasil Siklus III \\
\hline 1 & Nilai rata-rata tes formatif & 80 \\
2 & Jumlah siswa yang tuntas belajar & 11 \\
3 & Persentase ketuntasan belajar & 91.67 \\
\hline
\end{tabular}

Berdasarkan tabel diatas diperoleh nilai rata-rata tes formatif sebesar 80 dari 12 , siswa yang telah tuntas sebanyak 11 siswa dan 2 siswa belum mencapai ketuntasan belajar. Maka secara klasikal ketuntasan belajar yang telah tercapai sebesar 91,67\% (termasuk kategori tuntas). Hasil pada siklus III ini mengalami peningkatan lebih baik dari siklus II. Adanya peningkatan hasil belajar pada siklus III ini dipengaruhi oleh adanya peningkatan kemampuan guru dalam menerapkan pembelajaran penemuan (discovery) sehingga siswa menjadi lebih terbiasa dengan pembelajaran seperti ini sehingga siswa lebih mudah dalam memahami materi yang telah diberikan. Pada siklus III ini ketuntasan secara klasikal telah tercapai, 
sehingga penelitian ini hanya sampai pada siklus III.

\section{Refleksi}

Pada tahap ini akah dikaji apa yang telah terlaksana dengan baik maupun yang masih kurang baik dalam proses belajar mengajar dengan penerapan pembelajaran penemuan (discovery). Dari data-data yang telah diperoleh dapat duraikan sebagai berikut:

1) Selama proses belajar mengajar guru telah melaksanakan semua pembelajaran dengan baik. Meskipun ada beberapa aspek yang belum sempurna, tetapi persentase pelaksanaannya untuk masing-masing aspek cukup besar.

2) Berdasarkan data hasil pengamatan diketahui bahwa siswa aktif selama proses belajar berlangsung.

3) Kekurangan pada siklus-siklus sebelumnya sudah mengalami perbaikan dan peningkatan sehingga menjadi lebih baik.

4) Hasil belajar siswa pada siklus III mencapai ketuntasan.

\section{Revisi Pelaksanaan}

Pada siklus III guru telah menerapkan pembelajaran penemuan (discovery) dengan baik dan dilihat dari aktivitas siswa serta hasil belajar siswa pelaksanaan proses belajar mengajar sudah berjalan dengan baik. Maka tidak diperlukan revisi terlalu banyak, tetapi yang perlu diperhatikan untuk tindakan selanjutnya adalah memaksimalkan dan mepertahankan apa yang telah ada dengan tujuan agar pada pelaksanaan proses belajar mengajar selanjutnya penerapan pembelajaran penemuan (discovery) dapat meningkatkan proses belajar mengajar sehingga tujuan pembelajaran dapat tercapai.

\section{PENUTUP}

Dari hasil kegiatan pembelajaran yang telah dilakukan selama tiga siklus, dan berdasarkan seluruh pembahasan serta analisis yang telah dilakukan dapat disimpulkan sebagai berikut:

1. Pembelajaran dengan penemuan (discovery) memiliki dampak positif dalam meningkatkan prestasi belajar siswa yang ditandai dengan peningkatan ketuntasan belajar siswa dalam setiap siklus, yaitu siklus I $(58,33 \%)$, siklus II $(75 \%)$, siklus III $(91,67 \%)$.

2. Penerapan metode pembelajaran penemuan (discovery) mempunyai pengaruh positif, yaitu dapat meningkatkan motivasi belajar siswa yang ditunjukan dengan hasil wawancara dengan sebagian siswa, rata-rata jawaban siswa menyatakan bahwa siswa tertarik dan berminat dengan metode pembelajaran penemuan (discovery) sehingga mereka menjadi termotivasi untuk belajar.

\section{DAFTAR PUSTAKA}

Departemen Pendidiakan dan Kebudayaan, 1994. Petunjuk Pelaksanaan Proses Belajar Mengajar. Jakarta. Balai Pustaka.

KBBI. 1996. Edisi Kedua. Jakarta: Balai Pustaka.

Kemmis, S. dan Mc. Taggart, R. 1988. The Action Research Planner. Victoria Dearcin University Press.

Nur, Moh. 2001. Pemotivasian Siswa untuk Belajar. Surabaya. University Press. Universitas Negeri Surabaya.

Syafi'udin. 2002. Penerapan Pendekatan Konstruktivis dengan menggunakan Metode Penemuan untuk Meningkatkan Prestasi Belajar Siswa Kelas I MTsN Denanyar. Skripsi yang tidak dipublikasikan Universitas Negeri Surabaya. 